\title{
Fieldwork among Women in Nepal: A Female Researcher Revisits Her Experience
}

\author{
Mira Mishra
}

\begin{abstract}
In this paper, I argue, based on in-depth interviews with 75 rural women from 25 households in Nepal nearly eight years ago, that a reflection on fieldwork helps a researcher to critically review and critically appreciate one's own work and to identify challenges that can be helpful not only to the researcher but also other researchers. I describe three distinct stages of my fieldwork. The first one relates to the image I held regarding rural women's life and society as well as the information generation techniques I thought I ought to utilize before I actually went to the field. The second stage relates to the learning I gained during the fieldwork regarding rural women's life and society and the manner in which I actually went about generating information. The third stage relates to how I now reflect back on the lives women lead in rural areas as well as the techniques I utilized to generate information. In the concluding section, I attempt to identify the gains I made while I traversed through the three different stages of research.
\end{abstract}

Keywords: women, rural, experience, revisit, fieldwork

\section{Introduction}

I have been teaching Gender Studies/Women's Studies for more than two decades. Research is an integral part of my teaching. After engaging in research on gender issues for almost 25 years, I thought it was time for me to reflect on my own work. Nonetheless, "reflection is difficult. We have to step outside ourselves and look on ourselves as another person might ... [yet] "when we reflect on some topic, we try to understand it more deeply. We consider matters like context, assumptions, cultural biases, political influences and so on" (Weber, 2003: v). Reflection helps a researcher, while critically looking at one's own work, to appreciate it and identify challenges that would be helpful for future study. Apart from that there is the possibility that it might reveal our wrong assumptions, research methods, research questions, etc. That is scary to many researchers (Weber, 2003). I was scared too. Nonetheless, I was confident that reflection also provides researchers with the opportunity to share their own strategies to solve some of the unforeseen challenges one has to tackle during research including fieldwork.

This paper reflects on my Ph.D. field work. It is essential for a qualitative researcher to provide absolute transparency on the research process and protocol undertaken (Nolen and Talbert 2011, p. 267). What could be a better way to do this than to reflect on one's own work? My Ph.D. was about changes in women's lives in Nepal over a 60 -year period. First and foremost, my own life experiences motivated me to choose the topic. One of the criteria utilized to problematize research could be the researcher's own life experience (Uprety, 2013). I had experienced so many changes in my own life. For example, my mother never went to school, yet I was planning to enroll in the Ph.D. program. My mother, who is 80 years old, continues to think that menstrual blood and menstrual women are impure and polluting. My daughter, on the other hand, considers a 'period' simply as a biological condition associated with a woman. In addition, women's lives were in transition in Nepal particularly after 1990. Age at marriage had increased, fertility had declined, divorce was increasing, women's engagement in paid work was rising, etc. My own life experience, together with the transitions in women's lives in Nepal over a period of more than two decades forced me to seek answers to questions the changes raised. The questions about what led to the changes in women's lives, how to describe the changes and where to concretize these changes remained the major challenges. Conversations with women about their personal lives could resolve my problems.

I decided to interview 75 rural women from 25 patrilocal and patrilineal households in Nepal. Each household consisted of three women of different generations: motherin-law, daughter-in-law and an unmarried granddaughter. I did so in order to carry out a comparison between sets of three generations of women and identify the changes that were taking place across three generations who otherwise residents of a single household and faced and negotiated a set of circumstances inside and outside the household. To concretize the changes, I chose three social sites: menstruation, marriage, and motherhood. Four geographical locations were identified as my 'field'. My field included urban Kathmandu, rural Kathmandu, western hills and eastern Tarai. Field does not necessarily consist only of a geographical locale; instead it could be a person, an institution, or a house. Apart from different locations, 
I tried to include women from different ethnic and class backgrounds as interviewees. Women of Nepal differed widely by ethnicity not the least because there are more than 125 ethnic groups in Nepal (CBS 2012). Detailed conversation could furnish information I required to understand the processes of change. My mode of inquiry, therefore, was qualitative (see Kvale 1996). Fieldwork was the major part of my research work. I started fieldwork at the end of 2008 and continued it for almost six months.

\section{Qualitative vs Quantitative: Identifying appropriate methodology and method}

I was interested to bring to light women's everyday life experiences and their interpretation. As a Women's Studies teacher, armed with gender perspective - the perspective that social knowledge is largely androcentric and women's way of knowing - is as important as men's way of knowing. I was convinced that existing social knowledge was largely androcentric and not a reliable and complete knowledge base unless women's experiences and interpretations of the experiences are identified, respected, and accommodated into it.

Choosing a mode of inquiry, therefore, was a considerable challenge. Feminists' arguments against quantitative methods (Oakley 1981, Mies 1983) influenced my methodology to a large extent. The methodological debate that qualitative methods are best suited to feminist research emerged particularly after 1960 s, along with the introduction of Women's Studies. There were feminists who believed that "women's voice would unlikely to be heard in quantitative research" (Mies 1983: 120 in Oakley 1998: 780). In addition, Women's Studies, as a discipline is largely based on the assumption that "traditional social science ignores and marginalizes women ... and the areas of social life which has particularly concerned women (Oakley 1998:709). Letherby (2004) noted that many Women's Studies students, including herself, followed these views unconditionally. However, in later years, by reflecting on her work and other literature (Letherby 2004) realized that both quantitative and qualitative methods have their own merits and challenges. Oakley (1998) also distanced herself from her previous advocacy of qualitative method as the best method (1981) and argued that a judicious mix of quantitative and qualitative methods should be the best method for feminist research. As a Women's Studies teacher, my selection of methods was informed by this existing literature - although my primary mode of inquiry in this instance was mostly qualitative. Feminists have used all existing methods used by social scientists and some new ones as well (Letherby 2004: 179). I did the same. The tools I used consisted of questionnaire, personal interview, key informant interview, and focus group session and participant observation. I have here utilized the quantitative method only to gather information on socio-economic and demographic factors of both household members and interviewee women. On the other hand, I have employed the qualitative method to carry forth personal interviews that generated the bulk of information for this research.

\section{Numbers as a challenge}

Nevertheless, the qualitative mode of inquiry clearly and candidly reveals each process it has to go through - from perspective to identifying the problematic, to choosing methodology, to method and number, etc. It also provides information about the researcher's position, experience, and interpretation of the experience of the fieldwork. It does not provide further guidelines/prescriptions on the basis of one's research work as in quantitative research. It puts everything in front of the readers honestly and candidly.

After identifying qualitative research as the principle mode of inquiry, I had to consider the puzzle of number. I was in a dilemma on "how much data needs to be collected in quantity and type"? (Nolen and Talbert 2011: 264). In qualitative research, there is no clear-cut prescription on the number of inquiries or interviewees as there is in quantitative research (Kvale 1996, Nolen and Talbert 2011). When I started discussing specific numbers with experts in related fields, I received rather mixed and confusing reaction. I had 75 women as my interviewees. Those who were trained in quantitative research thought 75 interviewees were insufficient in order to make any generalization. On the other hand, for those who were trained in qualitative research, the number was far too big. One of the anthropologists I talked with at a very early phase of my research noted, "How could this research be qualitative when you have such a large number of interviewees, in addition to four physical locations of research? I rather suggest that you go to a village, and do in-depth studies there with just a few interviewees". An American anthropologist, who was in Nepal as a Fulbright scholar, expressed a similar view. When I talked with her about my proposal, she listened to me with a faint smile on her face. I thought she was not impressed with my proposal. I was wrong. She was impressed with the proposal, but the numbers were a big problem for her. She noted, "Mira, if you are going to write a book, this work is relevant. For a Ph.D., on the other hand, I suggest you delimit your locations, numbers and themes. Otherwise, your work won't be focused, but dispersed. As qualitative researchers, we need to go deeper into the issue in order to understand the social phenomenon". I was confused once more. Nonetheless, I knew My confusion was resolved to some extent by the work of (Nolen and Talbert 2011) who noted that there could be no fixed rule in qualitative research.

A renowned sociologist in Nepal tried to solve my problem by saying, "Your work is not a pure ethnography. Therefore, you don't need to worry about the numbers, issues, and locations. Your work is the combination of an ethnography and interpretative tradition. Therefore, you need both the breadth and the depth of the issues you are trying to examine". This was reassuring to me. More importantly perhaps, my principal supervisor shared in the view. In consequence, I reaffirmed that I will have 75 women as my interviewees. Regardless, and honestly speaking, I was not yet fully convinced. Until the day 
I had to defend my work orally in front of the research committee as part of the final process to receive the Ph.D. degree, the number and the location issues continued to haunt me.

\section{Understanding the 'field'}

As many novice researchers do, I had the impression that I must go somewhere to a rather far away location for my field research. I had to leave my place and my surroundings in order to gather information that I required about women's lives. The urge to leave the place where I was, was so strong that even while I was engaged in a literature review as a process of doing research, I was restless while thinking about a far-from-home "field". I kept thinking I was already late in getting to the field. I was unaware of the significance of the 'field'. But then it gradually dawned upon me that a "field" could be anywhere; at your own place, in your surroundings, at the college where you teach, or any factory where you worked. I felt much more relaxed when I went to one of the four field sites I had chosen for my field work. The cancellation of my previously held stipulation that that I must go to a "distant village" to pursue my field research was liberating for me.

\section{Entering the village}

When I first entered the village, I went to a tea shop where a group of people were gathered for tea and informal discussion. Almost all of them were men. A woman was making tea. Men were curious about my visit to their community. From which NGO did I come? To which political party did I belong? On which government project was I working? They had a wide range of questions. When I told them I was a teacher and was there for fieldwork as a part of my thesis writing, their expectation from me was suddenly lowered. I was not there to give them something. They said that many people come to the village to collect information for their theses. My agenda and I became somewhat commonplace and 'normalized'.

That way, I was accepted at one level. I was not harmful to the community because I was not politically motivated. And I had none of their important and high sounding agenda to pursue. I had told them I was there to collect information about women's lives. For them I was not an important person or one that the villagers in general had to be curious or vigilant about. I assumed that I received a green signal from the community to go ahead. It also suggested that women and women's issues have always been less valued than men and men's issues (Mead, 1935). Women are not as independent to speak with outsiders as men are. Most of them need men's approval to talk, whereas men don't need women's approval. Men's approval, directly or indirectly, is very significant in such situations. Therefore, whenever one goes to the field with women's issues, he or she should consider such facts and initiate appropriate steps. Before approaching your women interviewees, you have to meet up with local leaders (both women and men) and make them understand the objectives of your visit. If your work is not too political, if you do not dig up questions about household property, and if you are not there to specifically document incidents of violence against women, the community and the men would not object to your speaking with "their" women. When I go a household, I find that many women who have negotiated a tacit understanding or a more frontal permission from the men of the households to participate in the interview, the women will open up more easily. Once opened up, they will share with you their personal stories as well. This implies that it is comfortable to enter into women's lives through men. I made a few statements and posed a few very general questions to the men, particularly to those who were relatively better educated and informed than women. I informed about the objectives and of research and the kinds of information that I required - menstruation, marriage, and motherhood. Fortunately these turned out to be issues that the men of the households were least interested and least opposed to. They told me these were women's issues and it was only fitting that I should sit with their mothers, wives, sisters and daughters and ask about anything I wished to.

\section{Interviewee as "object" or "subject"}

At first, before going to the field, I thought of all rural women as a homogenous group. Second, I thought, if asked with politeness, the women would reveal, to a woman researcher, their stories rather fully. They would easily tell stories of victimhood, subordination and violence. I was wrong about this. As I found out later, Mohanty (2003) had noted that women were not victims all the time. My conceptualization that rural women are weak and victimized was falsified by their active lives in and out. In one moment, they would cry, and in the next, they would laugh. Their contribution to household subsistence was remarkable. Besides, their engagement in public life through savings and credit groups, political parties, village government, etc. had substantially elevated their self-image. It reminded me of Mohanty's "Under Western eyes "(2003). There she invalidates Western feminists for ignoring the agency role of third-world women. She also accuses feminists of falsely conceptualizing women as always weak, vulnerable and subordinate.

In one of the field sites, when I reached a tea shop, a few men were there with cups of tea. One woman was washing clothes at a nearby tap. I talked with those men about my work. I told them I was hoping to speak with women in the locality. The woman who was washing clothes suddenly disappeared in the meantime. After a few minutes, however, she came back with four other women in tow. They were looking at me with curiosity. One of them simply said, "People come to take information, talk sugary things, go back and never show up again. May be you are one of them?" It was really difficult on my part to convince them otherwise. I said I was "different". But thinking back maybe I was not different. I was interested in information on their lives but I had no particular interest in their lives as such. I was not motivated to form long term 
relationship with people I would talk to. During the initial phase of my field work, I was simply focused on collecting as much information as possible so that I could complete my Ph.D.

That is why whenever I met an interviewee, I started questioning her. I thought they would answer me easily. It did not occur to me that they would also have questions for me. Some of them wanted to know about family planning devices and the pros and cons of each of the devices, others were concerned about schooling of their daughters, and some others wanted to know about my own personal and family life. However, I was also reminded of Oakley's (1981) dictum that a feminist- based interviewing would consist of a strong relationship between the interviewer and the interviewee. The dictum made me change my perspective as well as relations with the interviewees to some extent. I deliberately became closer to them, developed more interest in them and their surroundings and respected their time and individuality. The interviews very often went well. It taught me a lesson as well.

\section{Choosing a season}

I chose winter to go to the field. One of the key reasons was that women would be freer during that time because winter is a slack season in terms of agriculture. This, however, was a half- truth. They did not have much time to engage in conversation even when they had finished their farm work. Middle-aged women in particular are engaged in several developmental and community activities. Since 1990, and particularly after the peace agreement between the government and the Maoists in 2006, when the Maoist rebels agreed to lay down arms following 11 years of armed conflict, there was a mushroom growth of CBOs, NGOs and Mothers' Groups in rural Nepal. And women were engaged in rapidly expanding social, economic, political and developmental arenas as active participants and representatives.

\section{Myth and reality about rural women}

My previous assumption that women in the village would be willing to talk with me had partially been falsified certainly not by the presence of hostility but by a lack of initial enthusiasm towards among many of the women. My assumption that I could be a good field researcher was based on the facts that I was a married woman, had given birth to child, was a teacher by profession and, most importantly for me, was curious to know about the lives the women were leading. But these attributes were not sufficient. When women knew I was visiting them, they gathered around me. A local leader with whom I had informal discussions about my fieldwork had informed the women earlier. Women who were gathered there were among those who were socially and politically engaged in the locality. We gathered in the premises of a local primary school that was closed because it was Saturday that day. The women gathered there had expected me to be a visitor from some rather ubiquitous NGOs that would provide them with small seed funds for investment or employment or some skill-related training. Later, I found out that a few NGOs had provided some seed funds to a few women there. One NGO had also trained a few women on vegetable farming. When I introduced myself to them as a teacher and researcher and described my purpose in visiting the village and speaking with them, many seemed to lose interest in me. Sita, a middle-aged woman who was active in local politics noted that there were so many women researchers who visit, take information from them and disappear. Jamuna, a Newar woman in her mid-fifties, and who ran a family shop along the roadside, added, "No one comes to give us anything, everybody comes to take something from us. By now we have become more batha (clever)". Juneli, an octogenarian Magar woman, who was listening to the conversation closely, noted, "Though you say you are a teacher and came here to talk with us, who comes so far to talk with village women like us without you receiving any monetary benefit? No one works without money these days". There was much disbelief in her voice. In the meantime, many left without showing interest in further conversation. I was somewhat speechless and nervous too for quite a while. Women were to become my primary interviewees and if I was unable to make them interested in me and my work, it would be prove costly to me. Nonetheless, I maintained my patience. I was reminded of the expression, "Fieldwork often puts your patience and tolerance on hard trial. You go to the field to learn about the other, but soon you realize that anything else you learn is about yourself, about your limits and your content" (Gross, 1999/2000, p. 80).

I then abandoned the whole idea of formal conversation with women at least for the time being. Unless you can make them feel interested in you, they will never have time for you, nor would they give honest answers to you. For example, one older generation woman was reluctant to continue a conversation with me despite my several requests. I had already interviewed her daughter-in-law and granddaughter. I had to complete in the interview with her because she was one of three women in the household that I needed to talk to identify intergenerational changes on menstruation, marriage and motherhood. I was at an impasse. But when I accidentally asked her about her maternal home (maiti), her face lit up. I asked her about her parents, siblings, location of her maiti, her last visit to the maiti, etc. She said, "why is this nani (this younger woman, meaning I) interested in such a nathe kura (valueless information), I am surprised". Her face and her smile suggested that she wanted to talk more about her life with me. She had accepted me. Thus the nature of the question we ask plays an important part in rapport building.

\section{Nature of Questions and Rapport Building}

Not all, whether men or women, in the village were willing to immediately speak with 'outsiders'. They were attentive, generally respectful, suspicious and calculating. As a researcher, it was a lesson I really needed. It taught me that a researcher ought not to jump to any conclusion 
without detailed exploration of the socioeconomic and cultural context of the 'field'. Cultural context is very important. I framed a few questions during the field work on women's maiti, which became an entry point into their lives. In Nepal, patrilocality is the predominant postmarital rule of residence. Women leave their birth homes at an early age as early marriage is common. In addition, most women enter into village exogamous marriage. Therefore, the maiti (parental home) has been an emotional, psychological and even physical refuge and solace for many women. That is why the questions about maiti turned out to be very significant. The questions, "where is your maiti?" and "how far is it from here?" pleased women very much. They were surprised as well as appreciative of the questions because the questions were both innocuous and endearing. The questions often made them laugh. A 40-year-old woman laughed loudly with appreciation in her eyes and said, "Why do you want to know about my maiti? No one has asked me that question for very long?" Another woman, aged 74, said: "I don't know why this nani (young woman) wants to know about ganthane kura (unimportant, valueless information) regarding my maiti." Her expression showed that she very much wanted to hold a conversation about her maiti and her relatives there. Kanchhi, another first-generation woman from a highcaste family, noted with a smile on her face and tears in her eyes, "We had never been asked such questions in our lifetimes, although I have been approached by so many men and women with questions. You took me to my past, nani. I am both happy and sad". Similarly, Juni, a middleaged Tamang woman who was listening to us, added: "To get married and to have children is a common thing for women. As such, there is nothing significant to talk about". And she laughed out loud. "What drew you here from so far away to listen to such inconsequential (nathe) information; that is what I can't understand," another lady from rural Kathmandu said. "Everyone goes through the menstrual period, everyone gets married, and gives birth to children, what is so significant about it? I don't see any significance in these things," another one said. I, however, knew that they were interested to talk with me. That is all that I myself wished for as a qualitative researcher.

\section{Selection of households}

In a qualitative interview, in Kvale's words, "many ... methodological decisions have to be made on the spot, during the interview" (1996, p. 13). I had the same experience. I needed 25 households with women of three generations living together. My initial impression, before I went to the field, was that I could easily locate such households, particularly in rural areas. I was wrong. It was a challenge to find households with women of three generations under one roof. It was even more difficult to locate such households in Dalit and poorer neighborhoods. People would say there are so many households where women in three generations are living. Of course they were living in the same house or close by, but most of them were not sharing the same kitchen. In a few households, though women in three generations were currently living under the same roof, the households had two or three independent kitchens. Most married sons who lived with their families and had separate kitchens. This particular living-together arrangement was not in keeping with the conventional definition of a household. It is important to consider, however, that if very close relatives who live under the same roof or in the immediate neighborhood - who own and work the family farm together, share rituals together, etc. - it may be warranted for certain specific purposes to regard them as belonging to a single household. In any case, in such instances it is extremely difficult to make a demarcation on when a household begins and ends. At first, when I started scanning the structure of the household in my field areas, I found that most households consisted of a couple and unmarried children. In other words, most households were a nuclear unit. Second, those households that I called nuclear units did not actually have completely nuclear characteristics. Women in such units would "own" and work a farm together and women in any of the units would not be paid wages for working the farm. Nucleation of a household often takes place over a long stretch of time and such units remain in a liminal state for long with respect to the nuclear (or otherwise) nature of a household. That nucleating units work together in a woman's in-law's farmland, share responsibility for helping aging in-laws and organize and participate in frequently held rituals together reinforces the joint nature of their householding. In addition, that children are taken care of by all units, including that of the in-laws, together further cements the joint nature of householding for a rather long period of time.

Both because the particular type of three-generation household I wished to study was relatively uncommon and the nuclear or joint nature of a household was often in a liminal state, I relaxed my definition of a threegeneration household somewhat. I decided to include a few households and women in my study even if they had stopped sharing a kitchen for less than five years. All in all, among the 25 households selected, 16 households consisted of women of three generations living under the same roof and sharing the same kitchen. Further, I included in my study a granddaughter only if she was at least 14 years of age so she could share with me her experience, both biological and social, of menarche and regular periods. Women in eight of the households lived under the same roof but did not share the same kitchen. In such households, the grandmothers shared the kitchen with a son and daughter-in-law with small children. In one household, the grandmother had been living separately in the same compound for the last two years since the son's family, including her granddaughters, had converted to Christianity while she followed another faith.

It should be noted that my definition of a household is different from the definition used by the decennial census of Nepal and by Kayastha and Shrestha (2003, p. 177). Both define a household as a unit with members who live together, have been sharing the same kitchen for more than 6 months, and who may not necessarily be related either by blood or by marriage. 


\section{In-depth interviews}

I full trusted in-depth interviews as the best method to understand women's lives. My fieldwork experience confirmed this belief. Therefore I do not regret choosing this particular tool. But I would like to share some of the methodological challenges I faced while conducting one-to-one interviews. I could not conduct one-to-one interviews with all women. For a few the tools did not work as they "should" have. Instead, during the interview session, several of my interviewees were surrounded by women who were close to them. For example, in a Tharu household in the rural Tarai, I wanted to talk separately with Gita, a middle-aged daughter-in-law of the household. To my surprise, Gita did not wish to be interviewed when she was by herself. Nor did her sisters-in-law and next-door neighbors let her do so. She was surrounded by $4-5$ women during the interview session. I tried to get rid of them, but I failed. I was in a dilemma as to whether I should leave her or continue the interview. In terms of standard interviewing manual I could not have allowed the gathered women to be present or intervene during the interview. On the other hand, had I tried any further to shoo the gathered women away, my interviewee may very well not have told her story she did. There was another dimension as well. If I had avoided her relatives and neighbors, she would have been hurt also. Disrespecting other women meant disrespecting her as well. I observed the situation closely. I realized that these women were closely connected with each other. They were sisters-in-law and next-door neighbors with whom my interviewee would have shared many aspects of life. I was convinced that if I talked with her in a group, she would tell her story better than in isolation. So I decided to continue the conversation with my interviewee. In the rural hills as well, women felt comfortable telling their stories when they were with other women. But it was not a universal rule. In Kathmandu and other urban areas where I conducted interviews, women wanted to be alone to tell their stories. As a qualitative researcher I learned from the field interview that each interview case and session is unique in certain ways. We have to respect the uniqueness of the case and accommodate it during interviews.

\section{What comes first: Focus group discussion or interview}

I had planned before going visiting the field that I will interview women first and then organize a few focus group discussions in order to inquire further about issues raised during the interviews. After a few interviews, I noticed that most women in the village felt excluded from the research process and wanted in. A few of them were even suspicious of me. Gauri, one of my interviewees, noted, "most women in the village are jealous of us. They think that we are privileged women because we are part of this research. Some of them even say that we get money from you. These illiterate women can't tolerate other women getting some opportunities. Sister (Didi), you don't listen to them". (Ironically, Gauri was illiterate herself.) A false message that I was there not for "all women in the settlement" but only for a selected few that I had already interviewed was circulated among women. I had to contradict this false message. Therefore, I changed my previous plan to conduct the interviews first. Instead I conducted a focus group session with women in order specifically to include more women of the settlement in my work. That way, I solved the problem of women's "exclusion". Most women wanted to speak with me, but I needed only a select few. The best way to solve the challenge was to conduct a focus group discussion first, so that women could feel they were not excluded. After the discussion, I could choose a few selected households and women for personal interviews.

The lesson that I drew from the process was that there is no fixed rule in qualitative research. A researcher should be attentive to the consequences of his or her work at each level and be ready to be flexible. If I were not flexible enough to alter the sequence of the use of the tool, I might have lost the trust that I had gained from the village residents including women. And I would have paid the price.

\section{Conversational Setting}

The conversations took place in various settings. I interviewed some women in the kitchen, some in the elevated section of the courtyard (pidi), some in the living room, and quite a few in the kitchen garden, the family farm, the family shop, and the bedroom. All conversations, however, took place in home surroundings. It was not a place that the women or I deliberately chose. The place of conversation was largely shaped by the women's world - that of the private sphere. In Kathmandu, the conversation often took place in the living room. In the western hills, most of the interviews were conducted either in the courtyard or the kitchen garden. In the eastern Tarai, I interviewed women in the terrace or courtyard. Because of my "high-caste" pedigree, Brahmin and Chhetri women sometimes invited me into their kitchen where they were working at the time. The narration of life took place even as they were cooking a meal. One first-generation woman from the western hills noted, "Nani, because we are similar by caste, you can come to my kitchen. We can hold our conversation there. I won't let members of other caste groups (aru jat) come to my kitchen. It is a high caste kitchen. Although there is no caste discrimination (jat-bhat) in the public world today, I still maintain it in my home. I have to make food ready before nine o'clock because my grandchildren go to school and my daughterin-law has gone out to collect fodder." A strong sense of caste purity was reflected in her voice.

\section{From general to specific: Strategies to enter into women's personal lives}

I had prepared two sets of questions. The first set consisted of general, household, and demographic questions. The second set consisted of questions related to personal and social life. I generally started a conversation with the 
general, relatively innocuous questions in order to make women feel at ease with me and my questions. I would generally start out with women of the first or second generation. My interviewees did not have to think much or make a serious attempt at recall to answer the initial questions. I asked them their name, location of their natal family, number of children, their educational attainment, etc. Not only were the questions easy to answer but the answers were publicly known and, as such, there was no reason for the "interviewee," other members of the family, and other onlookers who had gathered there to become wary. Several women, particularly those in the first generation, were unaware or forgetful of their own official name. They then had to turn to their sons, daughters-inlaw or others for help. Members of the family also helped the old ladies with some other initial questions. All those gathered there were, thus, willingly caught up with the process and, in consequence, "enlisted" as participants to the process. In the meantime, they also tacitly approved my agenda and waited for me to push ahead with my questions. The women I conversed with, in the meantime also sensed the approval of the members of the family in the process of unfolding themselves. In doing so, tacitly at least, they also approved me and my questions. Then I got down to relatively specific questions such as when did the women experience their first menstruation? Who did she share her experience with, and so on.

I then further specified my questions: how did a woman feel about and interpret menstruation? Did she consider it impure? And so on. And later on I started conversations about much more personal issues about her life such as her marital and familial relationships, marital conflict, negotiating, agency strategies, etc.

At the time of receiving general information, I deliberately sought out the presence of family members, including men members. That eased my entry into the household. Following the initial set of questions and once we started talking about the experience of the lady's first menstruation, I then politely requested other members to leave us alone so I could talk to the lady privately. I honestly told them that I was henceforth going to talk to the lady about her experience of menstruation, marriage and motherhood. I had told them that she would find it difficult to answer the questions in public. Such requests invariably worked out. I think that it worked out for two reasons. First, members of the family were already involved in my conversation at an initial stage. At this initial stage, the other members of the family could sense that they were not going to "lose" any specific private and valuable household information during the conversation. Second, the questions I would begin to ask during the next phase-questions on menstruation marriage and motherhood--were relatively 'valueless and worthless issues' for men in particular. I also started talking about the lady's natal home, often a very pleasant topic with women. My interviewees, in consequence, were further at ease conversing about these topics. It was "their topic," a topic for all women. It was difficult for men to be there joining in on the "woman talk". I myself felt quite at ease with the topics and the process. I was mostly able to obtain privacy with my interviewees easily during this latter phase.

In a few cases, however, some members of the family became curious and suspicious for a relatively extended period of time. In such cases, they stayed on longer during the interview. For several reasons, and in some other cases, it was impossible to avoid other women members of the family and women from the neighborhood during the interview. First, some houses stand so close to one another - and households and women share so many "things" together - that neighboring women sometimes found it difficult not to share in the conversation during the interview. The neighboring women thought, therefore, that they should legitimately be there; after all they shared so many "things" in their lives together. Second, they wanted to talk to me - to a person who they somehow took to be more informed and knowledgeable than themselves. They were not sure I would come to their house to speak with or interview them. Third, they came over in the hope that they might get a chance to speak their minds on the "womanly issues" they thought they had to weigh in on. As such, I let them stay during the interview. I did not want to hurt them either. I did, however, request them not to interfere during the interview session. I do not know whether sharing an interview with neighbors is methodologically valid or not. But, both as a researcher and as a person, I strongly believe that when you insist that women surrounding your interviewee setting leave the setting, your interviewee is bound to be slighted because she has been one with the neighborhood women through her life. As such, it is necessary both to respect your subject as well as the context within the context she lives in. The positivist way of knowing and interviewing that tends to enforce a hierarchy between the researcher, the interviewee and the onlookers, thus, is inappropriate in qualitative research.

\section{Insider and Outsider: Researcher's Position during Field Work}

I was aware that interviewees can mislead a researcher when there is a powerful disconnect between the researcher and the interviewees (Miller and Glassner 2012: 134). Oakley speaks about the nature of qualitative interviews in her writing and urges feminist researchers to conduct nonhierarchal interviews. I tried my level best to be close to my interviewees as well. Trust building is, however, a process, not a one-time event. I had built a fairly good relationship with most, although not all of the women respondents. But this relationship building did not occur in one or two meetings. It was not only a gradual process but also involved their perception of my background. It included her family members', particularly men's acceptance of you as a trustworthy person. That I asked for a tacit "go ahead" signal from the men of the household was instrumental as well. Further, that I approached interviewee by speaking with them their natal home, took sincere interest in their lives, respected them as persons, intently listened to them, and shared stories about my own life and the challenges I faced as a job holder, wife, mother, and daughter-in-law. It 
thus seems to be that it is impossible to build this kind of rapport during a social survey.

In addition, most of my interviewees and I shared many things in common. My sex and my gender both helped me become close to women I interviewed. Biologically we were females. We shared the same biological processes of menstruation. Most of us also shared motherhood. Socially we were women. Women in the first and second generations and I were both married, and given birth to and reared children. We had to live with the image of a wife, a mother and a daughter-in-law and perform our roles accordingly. I shared the biological and social condition of menstruation with women in all three generations. All these things brought the interviewees and me close together. It was because of these reasons that they wanted to listen to my stories. We laughed together and, at times, became sad together. Indeed, some women even took pity on me because of my social position as the mother of an only daughter. I had no son and "just one daughter". One of the respondents said, "bichari (you poor woman); though you are educated, hold a job and earn, I think you suffer more than us. Life of a sonless mother is very difficult. May be your mother-in-law has threatened you that she will arrange for a second grandson-giving daughter-inlaw? May be your husband has threatened you for the same reason? Who knows?" She stopped and looks around for approval. I recall Gyanu, another interviewee who said, "to have a son is a god's gift. Not everybody is lucky enough to have a son. I am poor but I have three sons". The message spread out like a bushfire in the settlement that I did not have a son and but only one daughter. I became a bichari (a powerless and pitiable woman) for many of them. Most of my interviewees appeared to themselves to be more powerful than me socially and religiously in that they were mothers of one or more son(s). That condition, however, helped me because I became somewhat loveable and supportable because of my weakness of not having had a son. I think this condition helped me build rapport as much as the conscious efforts I made in order to become an insider. Of course, "to be an insider or an outsider is a fluid status (Rabe, 2003, p. 150). In some ways, I was simultaneously becoming insider who was inevitable also an outsider (Kikumura, 1998, p. 142 in Rabe, 2003, p. 150).

I was, of course, an outsider in many ways. I had a different socioeconomic background than a majority of women in the first and second generation. I was university educated whereas a majority of them could not read or write. I was employed whereas a majority of women I conversed with had only a minimum level of public exposure. Still, they trusted me because I was honestly interested in their lives. I respected them as important individuals in their own right. My belief that they were equal to me and my conviction that their interpretation of the social world was as valuable as my interpretation sustained my research and, I think, brought me close to them. On the other hand, my different social positioning also had a certain benefit. Women in the youngest generation, in particular, were motivated to talk with me because of my educational and professional background. I was kind of a role model for many of them.

\section{Conceptualization of women as dependent and subordinated beings}

I had imbibed feminist writings on domesticity and child care (De Beauvoir, 1953, Friedan 1963, Sandberg, 2013) that discusses domesticity and childcare at length as important domains of women's subordination. I now wanted to explore if, and the extent to which, these aspects of subordination had experienced intergenerational change. I framed the questions accordingly. For example, I asked questions like "Does your husband help you in the kitchen?" and "Does your husband help you in child care?" Most women interviewees in the rural hills and Tarai laughed at the questions. I was somewhat confused. I could not figure out what went wrong with those questions. Women in Kathmandu were so much more interested in answering the questions. The questions were was so relevant for women in Kathmandu. The Kathmandu women were, of course, educated, employed and in their young adulthood, i.e. of the middle generation in terms of my study. They were overburdened by the work at home and the office which they labeled a "second shift" (see Hochschild and Machung, 1989). Younger women in urban areas, in particular, expressed great concern about help during child care. They were seriously worried about what the condition of motherhood and about who would help them to raise a child. But the same questions did not evoke a similar response from rural women in the same age group. When I asked those kinds of questions the women there thought I was so ignorant about their lives. Gayatri, one of the interviewees, noted that she was not worried about of raising a child. She further noted: "My husband does not look after children, nor does he help me in the kitchen. Children, in particular, raise themselves". Her older sister-in-law, who was not my interviewee but was listening to the interview immediately added, "We don't let our husbands enter the kitchen. The kitchen is our domain. We are the masters of that domain". Kanchhi, a 75-year-old interviewee, further added, "you see, nani, it is not our tradition to let men cook. It is a woman's duty whether she likes it or not. We women know how to cook and manage our homes; men don't'. A Magar woman from the western hills, in her mid-sixties noted who, "We gaule mahila (village women) know about nothing, neither how to read and write nor how to speak with outsiders. Vat vancha (agriculture and cooking) is the only space where we engage with certain skills. And, sometimes, we feel proud of our skills".

\section{Women's agency}

I changed quite a few of my interview questions thereafter. I took out the questions related to women's subordination in the domestic domain. I added a few new questions regarding women's agency. "Field work does cause one to change the questions and the categories, sometimes radically" (Phillips, 2001, p. 76). Early on I just could not 
figure out properly that women's subordination is context specific than universal. Women are not always weak and subordinate notwithstanding the dominant feminist conceptualization. Women, instead reshape their lives in different ways in different contexts (see Mohanty, 2003).

\section{Frustration as researcher}

Despite trying to be close to the interviewees as much as I could, I was disappointed in some instances. Sometimes I wanted, for example, to lead the conversation to the nature of marital relationships. The interviewees, on the other hand, would prefer to continue the conversation about maiti. Sometimes they wanted to continue the conversation on vegetable farming. At times, I wanted to speak with my interviewees on a one-to-one basis, but they would be surrounded by other women who would occasionally interject their own views. I was also sometimes upset when women had to temporarily halt an ongoing interview in order to attend to their unfinished work at home and family farm. But then, as often, I would immediately console myself that I might behave the same way if somebody turned up to interview me instead.

There was, however, one case which bothered me for days afterwards. I had selected one household in the Western Hills settlement, slowly informed the women there of why I was there and asked if I could speak with the women in the household. The household was just next to the one I was staying in. Then one long day I interviewed both the mother-in-law and daughter-in-law of the household. I also had a long conversation with the oldest son of the family as an informant. Now it was the granddaughter's turn. She was 20 years of age. She had completed high school and been studying at the Intermediate of Arts level. She, however, was very reluctant to talk to me. She started to intentionally avoid me. I was polite with her and stated my objectives there a couple of times hoping that she would somehow become convinced of my justifications and sit down with me for an interview. I also told her how my work might benefit students like her. In addition, I informed her that the information she provided was between her and me and would not be shared with anybody else. She then softened somewhat and sat down with me. She then answered a number of questions related to the qualities she preferred in a potential spouse and her attitude about love and arranged marriage. But she continued to maintain a studied silence for long periods of time in between answers. She gave very short answers even to very general and non-sensitive questions. I was beginning to become confused. This was the first time I had encountered such resistance. I was very soft with her, but she seemed quite indifferent to me. I left her that day and told her that I would return the next day, when I visited her once again. However, her mindset had not changed from it was during our previous encounter. I then told her again that I needed information on women from three generations from a single household. So, unless she was ready to talk to me, I would have no use for all the information I had gathered from her grandmother, mother and father. I once again told her that I was not there to distress her or to disrespect her. I was there because I wanted to talk to her by myself, understand her life and relate her life to the broader and changing social world. She then softened up a little. It was not a full welcome. But I was glad for the bare bone information that I could have from her.

\section{Conclusion: Reflections on fieldwork}

A reflection on fieldwork helps a researcher to critically review and critically appreciate one's own work and to identify challenges that can be helpful not only to the researcher but also other researchers. The quality of a qualitative research process largely rests on the progressive and candid revelation of the object of research. Beginning from a confusion on making a decision on the size of an initial batch of subjects to changing the criteria for identifying the nature of households to be interviewed both present challenges. So, does alternating oneself between an insider and an outsider in order to dig out in-depth personal information. I have shown how I tried to face and then identify such challenges as honestly as I could both for myself and for my readers.

This paper shows that a researcher's social position in the field is not fixed but fluid. The urge to become an 'insider is an essential rites de passage of doing qualitative research sometimes turns burdensome. I have shown that it is not always necessary to become an insider in order to gather personal information. Certain information could be gathered more efficiently becoming an outsider rather than an insider. Hence, a researcher is sometimes forced to choose between becoming an insider and an outsider to gather qualitative information.

Further, I drew a lesson from the fieldwork that there is no fixed rule in qualitative research. A researcher, instead, should keep eyes and ears wide open and become attentive to the flowing consequences of his or her work. Learning-based flexibility in approaching the object of research as well as subjects acquired key importance. This flexibility includes the understanding that field work and research is context specific and, as such, a researcher must be ready to reconstruct one's own self as well as the one's understanding of the life of interviewees as well as, community people and the society. Since the qualitative research is largely context specific, a fieldwork propels contextualized learning forward. For example, my knowledge of the socio-cultural context of Tharu women in Nepal was highly limited. In consequence, I began my fieldwork by asking child care related questions framed by my theoretical understanding of women as subordinate mothers and wives. I completely ignored women's agency in domesticity and childcare. But I immediately reframed the questions in a manner that gave full play to the agency of the mother and other women regarding child care.

My fieldwork also shows that a fieldworker should approach an interviewee with interest, respect, openness, honesty and as non-hierarchically as possible. An interviewee, during the process of an interview, should progressively be introduced to the researcher. This creates 
trust that, in turn, elicits valid information from the subject. Openness, honesty and respect in dealing with an interviewee allow an interviewer to authentically enter the lives of their subject.

Fieldwork consistently tests one's patience. Sometimes situations unexpectedly turn adverse. Interviewees can, for various reasons, become indifferent or even pointedly ignore a fieldworker. The only way out in such situation is to make a serious effort to dig out the reasons and accommodate one's work accordingly.

Finally, during fieldwork a fieldworker learns not about the subject but about oneself. Episodes of self-learning hit suddenly and hard. During such episodes one learns about your own limits and strengths. This self-learning stays with the researcher for long.

\section{References}

CBS (2012). National Population and Housing Census 2011. Kathmandu: Central Bureau of Statistics.

De Beauvoir, S. (1953). The Second Sex. New York: Alfred Knopf.

Freidan, B. (1963). The Feminine Mystique. New York: Dell.

Gross, T. (1999/2000). Realisations: A letter from the field. Cambridge Journal of Anthropology. 21(2): 80-83

Hochschild, A. R. and Machung, A. (1989). The Second Shift: Working Parents and the Revolution at Home. Viking Penguin.

Kayastha, R. P. and Shrestha, N. L. (2003). Housing and household characteristics and family structure. Pp. 173-211 in Population Monograph of Nepal. Volume 1. Kathmandu: Central Bureau of Statistics.

Kvale, S. (1996). Inter Views: An Introduction to Qualitative Research. London: Sage.

Letherby, G. (2004). Quoting and counting: An autobiographical response to Oakley. Sociology, 38(1): 175-89.

Mead, M. (1935). Sex and Temperament in Three Primitive Societies. London.

Miller, J. and Glassner, B. (2012). "The "inside" and the "outside": Finding realities in interviews", Pp 131-148 in David Silverman (ed) Qualitative Research, 3rd Edition. India: Sage.

Mohanty, C. T. (2003). Under Western eyes. in Feminism Without Borders: Decolonizing Theory, Practicing Solidarity. Durham: Duke University Press.

Nolen, A. and Talbert, T. (2011). Qualitative assertions as prescriptive statements. Educational Psychology Review, 23(2): 263-71.

Oakley, A. (1998). Gender, methodology and people's ways of knowing: Some problems with feminism and the paradigm debate in social science. Sociology, 32(4): 707-31.

Oakley, A. (1981). Interviewing women: A contradiction in terms?. In H. Roberts (ed.) Doing Feminist Research. London: Routledge.

Phillips, R, B. (2001). Can you go out without your head? Fieldwork as transformative experience. Anthropology and Aesthetics, 39: 61-77.

Rabe, M. (2003). Revisiting insiders and outsiders as social researchers. African Sociological Review, 7(2): 149-61.

Sandberg, S. (2013). Lean In: Women, Work, And the Will To Lead. New York: Alfred A. Knopf.

Uprety, L. (2013). Problematization as a critical step in research process: An overview. Nepalese Journal of Qualitative Research Methods, 5: 1-8.

Weber, R. (2003). Editor's comments: The reflexive researcher. MIS Quarterly, University of Minnesota, 27(4): 5-14.

Mishra, Mira PhD https://orcid.org/0000-0003-26293908 Professor, Central Department of Home Science and Women's Studies, teaches in the Graduate Program in Gender Studies, Tribhuvan University, Kathmandu. Her research and publications focus primarily on rural change, womanhood and women's sexuality. Her recently published articles include "Ethnicity and ethnic inequality: Recent interpretations from rural Nepal (2015) in Contributions to Nepalese Studies, "Reflections on teaching Women' Studies" in Indian Association for Women's Studies (2017), and "Livelihoods, households and womanhood in Nepal" in Linda Lindsey and Mehrangiz Najafizadeh (eds.), Women of Asia: Globalization, Development and Social Change (2019) in Routledge.

Email: miramishra1@gmail.com 